\title{
Polychaetes and oligochaetes associated with intertidal rocky shores in a semi-enclosed industrial and urban embayment, with the description of two new species
}

\author{
Julio Parapar · Enrique Martínez-Ansemil • \\ Carlos Caramelo $\cdot$ Rut Collado $\cdot$ Rüdiger Schmelz
}

Received: 25 June 2008 / Revised: 19 December 2008 / Accepted: 2 April 2009 / Published online: 6 May 2009

(C) Springer-Verlag and AWI 2009

\begin{abstract}
The species composition and relative abundance of the annelid benthic macrofauna (Polychaeta and Oligochaeta) inhabiting the rocky intertidal zone of the ria of Ferrol (Galicia, NW Spain) were studied during field collections, from 2000 to 2002 . A total of 14,619 specimens (11,585 polychaetes belonging to 76 species and 24 families and 3,034 oligochaetes belonging to 18 species and two families) were collected from 98 quantitative samples taken from 13 sampling sites. The general spatial distribution of the annelid fauna reflects an increase of the diversity from the inner to the outer part of the ria. The general patterns found in the annelid composition suggest that the assemblages were dominated by oligochaetes in the inner sheltered sampling sites and polychaetes in the outer more exposed sites. Several faunistical and taxonomical remarks on selected species are presented. Two new species of oligochaetes are described: Coralliodrilus artabrensis sp. n. and Pirodrilus fungithecatus sp. n. (Naididae, Phallodrilinae). A new biological index, based on the oligochaete/ polychaete ratio $(\mathrm{O} / \mathrm{P})$, is proposed as tool to evaluate environmental quality and to monitor future changes in the environment.
\end{abstract}

Keywords Annelida P Polychaeta - Oligochaeta . Intertidal zone $\cdot$ Faunal composition $\cdot$ New species $\cdot$ Spain

Communicated by H.-D. Franke.

J. Parapar $(\bowtie) \cdot$ E. Martínez-Ansemil · C. Caramelo .

R. Collado $\cdot$ R. Schmelz

Departamento de Bioloxía Animal, Bioloxía Vexetal e Ecoloxía,

Facultade de Ciencias, Universidade da Coruña,

Alejandro de la Sota 1, 15008 A Coruña, Spain

e-mail: jparapar@udc.es

\section{Introduction}

Polychaetes are relevant components of the marine benthic communities, and have been the subject of many works on benthic ecology all over the world and particularly in the Galician rias (e.g. Currás and Mora 1991; López-Jamar 1978, 1982; López-Jamar et al. 1995; Mora et al. 1982; Rodríguez-Castelo and Mora 1984; Sánchez-Mata et al. 1993). However, these studies were in most part devoted to soft intertidal or subtidal sediments, while the rocky intertidal zone was rarely investigated (Villalba and Viéitez 1988). Regarding oligochaetes, apart from the few data provided by Giere (1979) and Martínez-Ansemil (1990) on subtidal sediments, there is a total lack of ecological studies on the coasts of the Iberian Peninsula and particularly in intertidal rocky shores. In general, and despite some notable studies such as that by Healy (1996a) on the distribution of oligochaetes on an exposed rocky shore in southeast Ireland, little is known about the oligochaete fauna in rocky intertidal marine environments in most parts of the world.

The polychaetologists McCann and Levin (1989), referring to the lack of knowledge on marine oligochaetes, emphasized that "future research efforts on the ecology and biology of this ecologically relevant annelid group are seriously needed". Giere (2006), in a brief analysis of the recent literature dealing with the ecology and biology of marine oligochaetes, stated that the ecological role of oligochaetes in eulittoral ecotones "requires at least as much intense scientific attention as do polychaetes" and considers that "the lack of new ecological and biological studies on marine Oligochaeta, since the 1982 review (Giere and Pfannkuche 1982), is disturbing".

The ria of Ferrol is a long, narrow and heterogeneous embayment located at the NW corner of the Iberian Peninsula. It has a dense human population and important 
industrial activities resulting in high pollution records, especially at its inner part (Graña-Carrodeguas and Macías 1987; Barreiro-Lozano et al. 1988; Cobelo-García and Prego 2004). Over the last three decades, six doctoral theses and more than 25 published papers have dealt with many benthic invertebrate groups in this area (i.e. Porifera, Mollusca, Polychaeta, Isopoda, Ascidiacea, and meiofauna); most of these works, as is the case with those on the Polychaeta, deal exclusively with taxonomy and faunistics (e.g. Parapar 1991, Parapar et al. 1992a, 1993a, 1994a, 1995). In contrast to this, the oligochaete fauna of the ria of Ferrol remains completely unknown as is almost the case overall for the coasts of the Iberian Peninsula. In fact, the marine and brackish-water oligochaetes identified from the peninsula are scarce; to date, 21 species have been reported, of which 11 have been found in Galicia, and exclusively in subtidal sediments (Giere 1979; Martínez-Ansemil and Giani 1980, 1987; Martínez-Ansemil 1982, 1984, 1993). Despite the high number of new species of oligochaetes described from marine habitats along the last three decades all over the world, mainly as a result of the contributions by C. Erséus (e.g. Erséus 1982a, 1990a, 1992, 2002), the actual oligochaete diversity in intertidal rocky shores still remains poorly known.

The aim of the present work is to ascertain the diversity of the polychaete and oligochaete fauna in the intertidal rocky shores along the ria of Ferrol, collecting material for an accurate taxonomic inventory. Also through a joint analysis of both annelid groups at the species level, some general ecological considerations are reported by comparing their abundance in the different sampling localities. Finally, considering the lack of specialists in animal taxonomy nowadays, we prove a new biological index, based on the oligochaete/polychaete ratio $(\mathrm{O} / \mathrm{P})$, which can be used as a rough tool to evaluate environmental quality and to monitor future changes in environmental conditions in areas highly susceptible to acute pollution events, as is the case of the Galician coast.

\section{Methods}

The ria of Ferrol (Fig. 1) is $15 \mathrm{~km}$ long, located at $43^{\circ} 27^{\prime}-$ $43^{\circ} 30^{\prime} \mathrm{N}$ and $8^{\circ} 09^{\prime}-8^{\circ} 21^{\prime} \mathrm{W}$. Two small streams (Xubia and Belelle) constitute the most important freshwater inputs. The water exchange between the ria and the shelf occurs through a narrow channel $2 \mathrm{~km}$ long and $350 \mathrm{~m}$ wide. The main factor controlling the water exchange is the tidal forcing, inducing a near-periodic circulation. This area is highly populated and an important industrial center on the coast of Galicia, with shipyards, a busy commercial port, and metallurgic industries. Most of the human population and the industries are located at the inner part of the ria, which is highly polluted. Industrial and urban sewage effluents were generally flowing into the ria with no previous treatment (Barreiro-Lozano et al. 1988; Cobelo-García and Prego 2004; Graña-Carrodeguas and Macías 1987).

The intertidal habitat consists of stable bedrock covered by seaweeds in the outer oceanic zone, whereas the inner area is characterized by more sheltered conditions, and here
Fig. 1 Map of the study area, the ria of Ferrol, showing geographical position of sampling stations (Sts. 1-13) and location of main industrial activities. Stations more extensively sampled (St.2-St.5) are marked with an encircled dot. The harbour in the outer part of the ria is currently under construction. A narrow channel (St.2; St.12; St.13) separates the inner part (St.3-St.11) from the outer part (St.1) of the ria

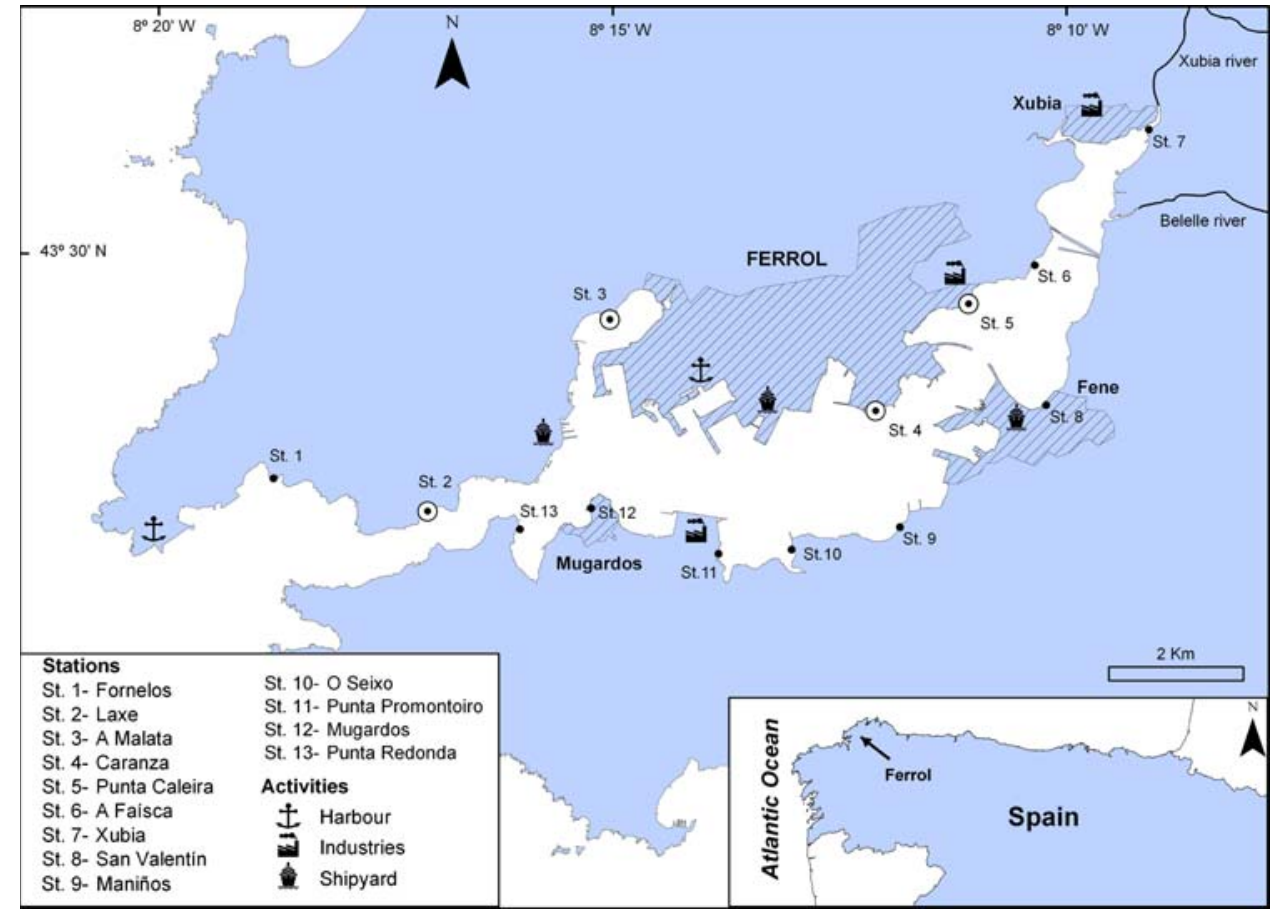


extensive mudflats cover most of the lower mesolittoral levels. The dominant intertidal zones on rocky shores are those composed by the seaweeds Pelvetia canaliculata (L.) Decaisne and Thuret, Fucus spiralis L. and Fucus vesiculosus L. (both alone or growing on beds of the bivalve Mytilus edulis L.) in the most sheltered zones, and Fucus serratus L., Chondrus crispus Stackhouse, Gigartina spp. and Himanthalia elongata (L.) S.F. Gray in semiexposed areas. According to Granja et al. (1992), the vegetation of this ria has a remarkably northern character, particularly at the supralittoral and upper mesolittoral fringe.

Thirteen intertidal stations, located at north and south shores of the ria (Fig. 1), were sampled twice, in autumn 2000 and spring 2001. In addition, and based on the results of this first survey, four of these stations (Sts. 2-Laxe, 3-Malata, 4-Caranza and 5-Caleira) were seasonally sampled again in 2001-2002 with the same periodicity. The main biotic assemblages and zones were identified, their length measured, and the upper and lower limit of each zone measured in relation to chart datum (CD) using a level. High measurements were taken along the shore transects, at successive intervals, from the water line at the time of low water. Positions in relation to $\mathrm{CD}$ were later calculated by adding of the height of the tide above $\mathrm{CD}$ given in tide tables. Figure 2 shows the distribution of the different zones at the more extensively sampled four stations. In each zone, two samples of $20 \times 20 \mathrm{~cm}$ surface were taken at a time, by scraping off the rocky substratum. Scrapped material was subsequently washed through a $500 \mu \mathrm{m}$ mesh sieve using seawater. After collection, samples were fixed in the field with $4 \%$ buffered formaldehyde solution. In the laboratory, annelids were sorted under a stereomicroscope, preserved in $70 \%$ ethanol, and identified to the species level if possible and then counted. A total of 98 quantitative samples were taken.

Given the lack of knowledge of oligochaetes in this area, the inventory resulting from this survey was supplemented with qualitative samples taken sporadically in soft bottoms with a corer.

To study oligochaetes, a number of specimens were stained with paracarmine or haematoxylin. Stained and unstained material was then passed through an ethanolxylol gradation series and whole-mounted in Canada balsam. Some Naididae [including the former families Naididae Ehrenberg, 1828 and Tubificidae Vejdovský, 1876 according to the rule of ICZN (ICZN 2007: Opinion 2167 (Case3305); see also Erséus et al. (2008)] were dissected prior to mounting. For accurate identification and complete description of some taxa, additional samples were taken in selected stations for in vivo observations. Enchytraeids
Fig. 2 Diagrams showing zonation pattern of organisms at the four stations sampled more extensively (Sts. 2-5). Organisms are not drawn to scale, and only selected species are shown

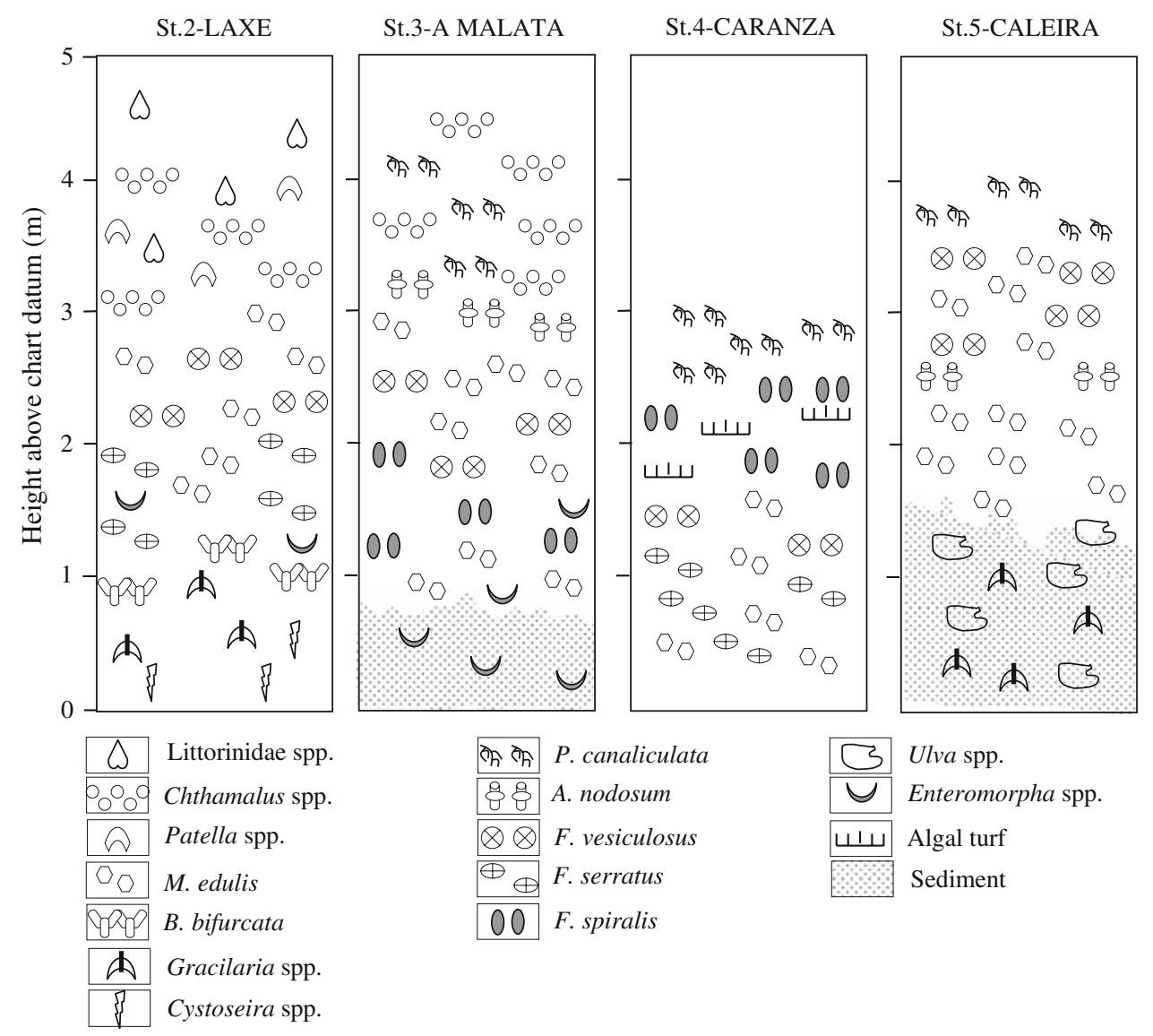


were then fixed in $70^{\circ} \mathrm{C}$ hot Bouin's fluid, stored in ethanol, stained, and whole-mounted as described earlier. Taxonomic descriptions of the enchytraeids will be provided elsewhere.

Polychaetes and oligochaetes were identified using a stereomicroscope and a light microscope provided with interference contrast optics. Line drawings were made by means of a camera lucida drawing tube. Micrographs were taken with a digital camera. The type series of the new species were deposited at the Museo Nacional de Ciencias Naturales (MNCN), Madrid, Spain. Some selected specimens of Eulalia clavigera (Audouin and Milne-Edwards) were deposited in the Zoologisk Museum (ZMUC), Copenhagen, Denmark.

Remaining specimens are kept in the personal collections of the authors: Enchytraeidae (R.M. Schmelz), Naididae (E. Martínez-Ansemil) and Polychaeta (J. Parapar).

Samples were taken from the following stations (Fig. 1) and zones [Ascophyllum nodosum (L.) Le Jolis (Asc); Bifurcaria bifurcata R. Ross; (Bif); C. crispus (Cho); Overhang (Ovh); Fucus ceranoides L. (Fce); F. serratus (Fse); F. serratus + M. edulis (FseM); F. spiralis (Fsp); F. spiralis $+M$. edulis (FspM); F. vesiculosus (Fve); F. vesiculosus + M. edulis (FveM); Gigartina spp. (Gig); Lomentaria articulata (Hudson) Lyngbye (Lom); M. edulis (Myt); P. canaliculata (Pel); Sediment (Sed)]:

St.1: Fornelos $\left(43^{\circ} 28^{\prime} 07^{\prime \prime} \mathrm{N}-8^{\circ} 18^{\prime} 52^{\prime \prime} \mathrm{W}\right)$. Semiexposed. Placed at the mouth of ria. Sandy beach with rocks [FveM, Lom, Cho, Ovh]. St.2: Laxe $\left(43^{\circ} 27^{\prime} 51^{\prime \prime} \mathrm{N}-\right.$ $\left.8^{\circ} 17^{\prime} 10^{\prime \prime} \mathrm{W}\right)$. Semiexposed. Placed at the channel of ria. Sandy beach with rocks. [Fve, Myt, Fse, Bif] (Fig. 2). St.3: A Malata $\left(43^{\circ} 29^{\prime} 22^{\prime \prime} \mathrm{N}-8^{\circ} 15^{\prime} 09^{\prime \prime} \mathrm{W}\right)$. Sheltered. Mud flat with rocks at the bottom of a closed bay in the medium part of ria. [FveM, FspM, Fsp] (Fig. 2). St.4: Caranza $\left(43^{\circ} 28^{\prime} 37^{\prime \prime} \mathrm{N}-8^{\circ} 12^{\prime} 14^{\prime \prime} \mathrm{W}\right)$. Sheltered. Mud flat with rocks and stones at medium part of the ria. [Fve, FveM, FspM, Fse, Fsp] (Fig. 2). St.5: Punta Caleira $\left(43^{\circ} 29^{\prime} 28^{\prime \prime} \mathrm{N}-\right.$ $\left.8^{\circ} 11^{\prime} 11^{\prime \prime} \mathrm{W}\right)$. Sheltered. Mud flat with rocks [Fve, FveM, Asc] (Fig. 2). St.6: A Faísca $\left(43^{\circ} 29^{\prime} 46^{\prime \prime} \mathrm{N}-8^{\circ} 10^{\prime} 27^{\prime \prime} \mathrm{W}\right)$. Sheltered. Mud flat with stones at the inner part of ria. [Fve]. St.7: Xubia $\left(43^{\circ} 30^{\prime} 51^{\prime \prime} \mathrm{N}-8^{\circ} 09^{\prime} 11^{\prime \prime} \mathrm{W}\right)$. Sheltered. The innermost station of the ria, on the mouth of Xubia stream. Mud flat with stones. [Fce]. St.8: San Valentín $\left(43^{\circ} 28^{\prime} 38^{\prime \prime} \mathrm{N}-8^{\circ} 10^{\prime} 21^{\prime \prime} \mathrm{W}\right)$. Sheltered. Mud flat with stones, seasonally covered with green algae, at the inner part of ria. [Fsp]. St.9: Maniños $\left(43^{\circ} 27^{\prime} 41^{\prime \prime} \mathrm{N}-8^{\circ} 11^{\prime} 58^{\prime \prime} \mathrm{W}\right)$. Sheltered. Muddy to sandy flat with stones. [Myt, Fve]. St.10: O Seixo $\left(43^{\circ} 27^{\prime} 30^{\prime \prime} \mathrm{N}-8^{\circ} 13^{\prime} 10^{\prime \prime} \mathrm{W}\right)$. Sheltered. Sandy to muddy flat with stones. [Fve, Myt, Gig]. St.11: Punta Promontoiro $\left(43^{\circ} 27^{\prime} 29^{\prime \prime} \mathrm{N}-8^{\circ} 13^{\prime} 58^{\prime \prime} \mathrm{W}\right)$. Sheltered. Sandy to muddy flat seasonally covered with green algae [Myt]. St.12: Mugardos $\left(43^{\circ} 27^{\prime} 51^{\prime \prime} \mathrm{N}-8^{\circ} 15^{\prime} 22^{\prime \prime} \mathrm{W}\right)$. Sheltered.
Sandy flat with rocks and stones. [Fsp, Fve, Fse]. St.13: Punta Redonda $\left(43^{\circ} 27^{\prime} 41^{\prime \prime} \mathrm{N}-8^{\circ} 16^{\prime} 09^{\prime \prime} \mathrm{W}\right)$. Semiexposed. Sandy flat with numerous rocks and stones at the channel of ria. [Myt, FveM, Fse].

\section{Results}

Taxonomy and faunistics

List of species

Table 1 lists the species identified. Some oligochaetes appear as "indet"; most of them are immature individuals, which could not be identified to the species level. Raw data concerning sampling and species composition per sample are available through the authors.

\section{Faunistical and taxonomical remarks}

Eulalia clavigera (Audouin and Milne-Edwards, 1833). St.1: FveM 3; Cho 1; Ovh 14. St.2: Myt 5; Fse 6; Fve 3. St.3: FveM 3. St.4: Fve 1; Fse 1; Fsp 1; FveM 5; FseM 3. St.9: Myt 1. St.12: Fve 1. St.13: Myt 1; FveM 1; Fse 5. Bonse et al. (1996) demonstrated that Eulalia viridis (Linnaeus, 1767) is a complex of species in northern Europe enclosing two species: E. viridis s.s. from Denmark, German and Swedish waters and E. clavigera from southern waters of England and France. Alós (2004) acknowledged this proposed change of species denomination for specimens reported from ibero-balearic waters. Our identification of Ferrol specimens as E. clavigera was confirmed by Dr. Eibye-Jacobsen and a selection of specimens was deposited in his museum with catalogue numbers ZMUCPOL-1897/98.

Harmothoe cf. andreapolis (McIntosh, 1874). St.12: Fse 1. The only specimen found in the Fucus serratus zone of St.12-Mugardos fits well with the description and drawings of this species provided by Parapar et al. (1992b); these authors reported this species from the same locality in the ria which was the first record in the Iberian Peninsula. Nevertheless, some discrepancies with the description provided by Tebble and Chambers (1982) related to central antenna, elytra and notosetae prevent a more accurate identification.

Ampharete sp. St.2: Bif 1. The only specimen found in St.2-Laxe fits well with the description of Ampharete finmarchica (Sars, 1865), a boreal species reported by Parapar et al. (1993a) in the same area. However, a recent examination of some specimens by Dr. I. Jirkov (pers. comm.) questions this identification. According to him, the shape of the paleae (with gradually tapering end) and number of abdominal 
Table 1 List of taxa found in this work

\section{Orbinidae}

Nainereis laevigata (Grube)

Spionidae

Aonides oxycephala (Sars)

Malacoceros fuliginosus (Claparède)

Malacoceros tetraceros (Schmarda)

Polydora caeca (Oersted)

Polydora ciliata (Johnston)

Polydora flava Claparède

Polydora hoplura Claparède

Prionospio multibranchiata Berkeley

Prionospio steenstrupii Malmgren

Pygospio elegans Claparède

Spio martinensis Mesnil

Streblospio shrubsolii (Buchanan)

Cirratulidae

Cirratulus chrysoderma Claparède

Cirratulus cirratus (Müller)

Cirriformia tentaculata (Montagu)

Dodecaceria concharum Oersted

Tharyx marioni (Saint-Joseph)

Capitellidae

Capitella capitata (Fabricius)

Arenicolidae

Arenicolides branchialis (Audouin and Milne-Edwards)

Branchiomaldane vicenti Langerhans

Phyllodocidae

Eteone longa (Fabricius)

Eulalia clavigera (Audouin and Milne-Edwards)*

Eumida sanguinea (Oersted)

Phyllodoce laminosa Savigny

Phyllodoce mucosa Oersted

Polynoidae

Harmothoe cf. andreapolis (McIntosh)*

Harmothoe impar (Johnston)

Lepidonotus clava (Montagu)

Sigalionidae

Pholoe inornata Johnston

Sthenelais boa (Johnston)

Hesionidae

Kefersteinia cirrata (Keferstein)

Syllidae

Autolytus benazzi Cognetti

Brania pusilla Dujardin

Exogone naidina Oersted

Haplosyllis spongicola (Grube)

Myrianida pinnigera (Montagu)

Odontosyllis ctenostoma Claparède

Parapionosyllis labronica Cognetti
Table 1 continued

Sphaerosyllis hystrix Claparède

Sphaerosyllis pirifera Claparède

Sphaerosyllis taylori Perkins

Syllides edentatus (Westheide)

Syllis amica Quatrefages

Syllis cf. armillaris Müller

Syllis gracilis Grube

Syllis parapari San Martín and López

Syllis prolifera Krohn

Syllis vittata Grube

Chrysopetalidae

Paleanotus chrysolepis Schmarda

Nereidae

Hediste diversicolor (Müller)

Hediste cf. diversicolor (Müller)

Micronereis variegata Claparède

Perinereis cultrifera (Grube)

Perinereis marionii (Audouin and Milne-Edwards)

Perinereis oliveirae Horst

Platynereis dumerilii (Audouin and Milne-Edwards)

Glyceridae

Glycera tridactyla Schmarda

Sphaerodoridae

Sphaerodoridium claparedii (Greeff)

Lumbrinereidae

Lumbrineris funchalensis (Kinberg)

Lumbrineris gracilis (Ehlers)

Lumbrineris impatiens (Claparède)

Lumbrineris latreilli Audouin and Milne-Edwards

Dorvilleidae

Ophryotrocha labronica Bacci and La Greca

Sabellariidae

Sabellaria alcocki Gravier

Pectinariidae

Lagis koreni Malmgren

Ampharetidae

Ampharete sp*.

Terebellidae

Amphitritides gracilis (Grube)

Polycirrus sp.

Terebella lapidaria Linnaeus

Sabellidae

Amphiglena mediterranea (Leydig)

Brachiomma lucullana (delle Chiaje)

Fabricia stellaris (Müller)

Potamilla torelli Malmgren

Serpulidae

Pomatoceros lamarckii (Quatrefages) 
Table 1 continued

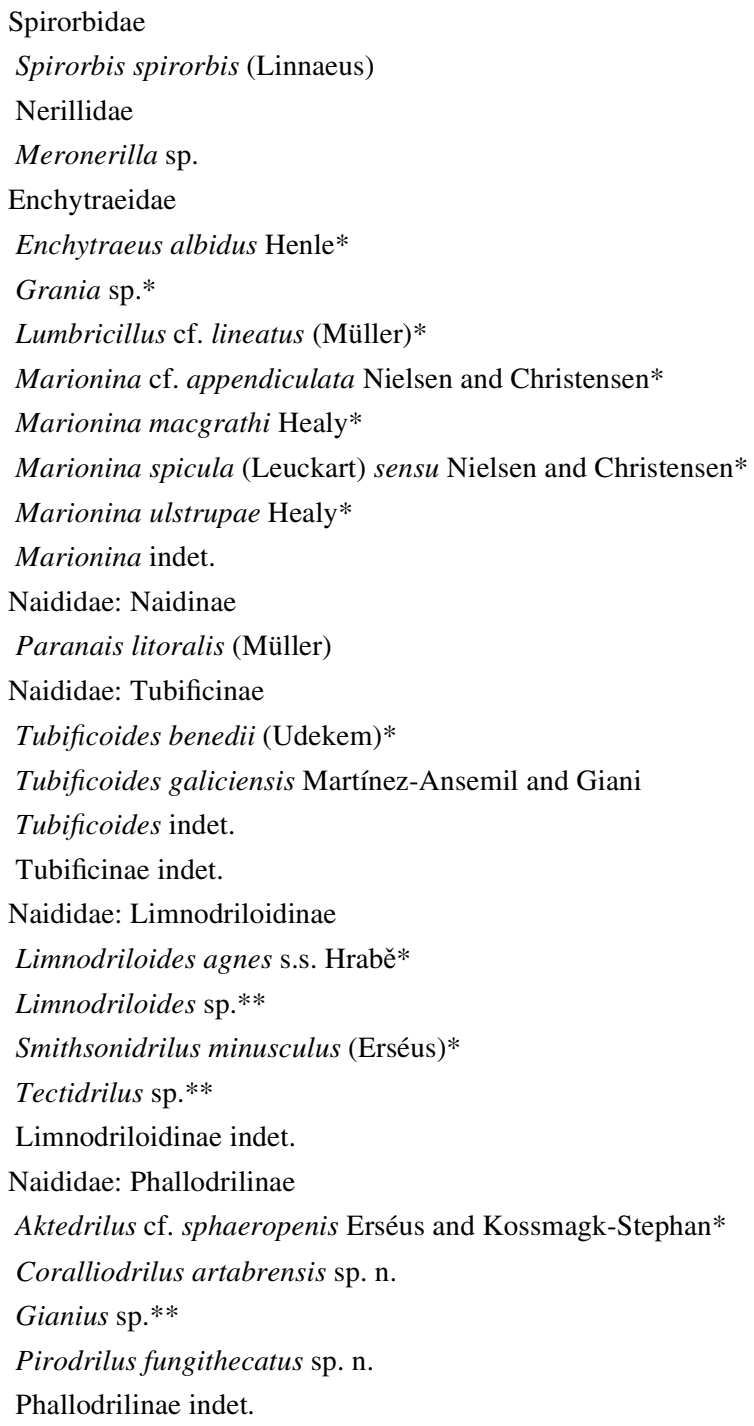

Spirorbidae

Spirorbis spirorbis (Linnaeus)

Nerillidae

Meronerilla sp.

Enchytraeidae

Enchytraeus albidus Henle*

Grania sp.*

Lumbricillus cf. lineatus (Müller)*

Marionina cf. appendiculata Nielsen and Christensen*

Marionina macgrathi Healy*

Marionina spicula (Leuckart) sensu Nielsen and Christensen*

Marionina ulstrupae Healy*

Marionina indet.

Naididae: Naidinae

Paranais litoralis (Müller)

Naididae: Tubificinae

Tubificoides benedii (Udekem)*

Tubificoides galiciensis Martínez-Ansemil and Giani

Tubificoides indet.

Tubificinae indet.

Naididae: Limnodriloidinae

Limnodriloides agnes s.s. Hrabě*

Limnodriloides $\mathrm{sp} . * *$

Smithsonidrilus minusculus (Erséus)*

Tectidrilus sp.**

Limnodriloidinae indet.

Naididae: Phallodrilinae

Aktedrilus cf. sphaeropenis Erséus and Kossmagk-Stephan*

Coralliodrilus artabrensis sp. $\mathrm{n}$.

Gianius sp.**

Pirodrilus fungithecatus sp. $\mathrm{n}$.

Phallodrilinae indet.

* Species with faunistical and taxonomical remarks in text. **Probably new species, to be described elsewhere

chaetigers (12) suggest that the Ferrol material belongs to the "lindstroemi group". The only Ampharete species reported hitherto in the Iberian Peninsula, apart from A. finmarchica, is Ampharete acutifrons (Grube, 1860), which differs from our Ampharete sp. in having longer abdominal neuropodial cirri and pygidial papillae.

Enchytraeus albidus Henle, 1837 s.l. St.4: $\quad$ Fsp 2. Two specimens were found, one of them mature; they differed from those of northern populations in the small size of the gland cells covering the spermathecal ectal duct and in a widening of the midsection of the vas deferens up to ca. $60 \mu \mathrm{m}$ in diameter; a trait described for E. mediterraneus Michaelsen, 1926, a member of a group of species morphologically close to E. albidus. The entire E. albidus - group is in need of revision. First record for Galicia. Cosmopolitan.
Grania sp. St.5: FveM 1. A single mature specimen, investigated in vivo and as stained whole-mount. The character mosaic did not agree fully with any of the described species. Possibly an accidental find, since species of Grania generally live in sublittoral, truly marine sediments. First record of Grania for Galicia.

Lumbricillus cf. lineatus St.2: Myt 1. St.3: Fsp 58; FveM 70. St.4: Fve 12; Fse 33; Fsp 74. St.8: Fsp 197. St.12: Fsp 1. Spermathecae vary among specimens, as between forms described for L. rivalis Levinsen, 1883, L. kaloensis Nielsen and Christensen, 1959, L. lineatus (Müller, 1774) in Ude (1929) but not in Nielsen and Christensen (1959), $L$. rubidus Finogenova and Streltsov, 1978, or L. enteromorphae von Bülow, 1957. More than one species may be involved, but most specimens appear to belong to one species. Since a similar form was found to be common in sediments of the Baltic Sea (Schmelz, unpublished observations, see also Timm 1999) it seems that this is the species usually identified as L. lineatus, the most-often cited Lumbricillus species in the European marine littoral. However, this identification requires confirmation by resampling of the localities, investigation of living material, and a systematic revision of the nominal species in question.

Marionina cf. appendiculata Nielsen and Christensen, 1959. St.3: FveM 4. St.4: Fve 5; Fsp 23. St.5: Fve 10. [Identification includes the observation of four specimens in vivo]. Specimens do not fully agree with the original description, e.g. coelomocytes of the four living specimens are pale and not "rather coarsely granulated" (Nielsen and Christensen 1959). The specimens may therefore represent a different species, perhaps a new one. Some specimens had small subneural glands in all segments from III on.

Marionina macgrathi Healy, 1996. St.3: Fsp 1. St.4: Fve 2; Fsp 598. St.5: Fve 26. St.13: FveM 1. [Identification includes the observation of twenty specimens in vivo]. Specimens are in good agreement with the detailed original description. Noteworthy are the conspicuous transverse copulatory body muscles, accurately described and figured in Healy (1996b, p. 1289, Fig. 1c), but misunderstood there as surface striations of the clitellum. A further diagnostic character in our material is a large subneural gland in XIII, a character not dealt with in Healy (1996b). First record of the species after the original description which was based on material from a wave-exposed rocky shore in SE Ireland.

Marionina spicula (Leuckart 1847) sensu Nielsen and Christensen, 1959. St.4: $\quad$ Fsp 69. St.5: FveM 5. M. spicula is a mesopsammobiont specialist (Giere 1971) and therefore, the finds in our samples from rocky shores are probably accidental. First record for Galicia and Spain. Widely distributed in Europe, Iceland, Greenland, Atlantic coast of U.S.A., and Bermuda. 
Marionina ulstrupae Healy, 1996. St.2: Fve 1. St.3: FveM 1. St.4: Fve 1; Fse 3; Fsp 1. [Identification includes the observation of three specimens in vivo]. Specimens are in good agreement with the original description, and easily recognized by the peculiar coelomocytes with longitudinal striations (comp. Healy 1996b, p. 1291, Fig. 2d), which show well, even in ethanol-fixed specimens. First record of the species after the original description of specimens from a wave-exposed rocky shore in SE Ireland.

Tubificoides benedii (Udekem, 1855). St.3: $\quad$ FveM 187. St.4: FveM 6. St.5: Fve 13; FveM 20. St.10: Gig 1. St. 12: Fve 9; Fse 14. First record for the Iberian Peninsula. Very common in estuaries of the Northeastern Atlantic coasts, also present on the Atlantic coast of North America.

Limnodriloides agnes Hrabě, 1967 s.s. St.13: $\quad$ FveM 1. First record for the Iberian Peninsula. It is a common species, previously known from Western Australia, China, Canary Islands, Mediterranean and Black Seas.

Smithsonidrilus minusculus (Erséus, 1983). St.3: $\quad$ Sed 2. Except for the spermathecal ducts, our specimens are in good agreement with the original description. The spermathecal ducts of $S$. minusculus from Ferrol are short and without constriction as those of the Caribbean and Hawaiian material (Erséus 1990b). First record for Europe and Eastern Atlantic coasts. Previously known from Western Australia, Northern Territory, Queensland, China, Hawaii, Bermuda and Belize.

Aktedrilus cf. sphaeropenis Erséus and KossmagkStephan, 1982. St.13: FveM: 1. This specimen belongs to a small group of Aktedrilus species which have posterior prostate glands that are not associated with the walls of the penial sacs. The general morphology and arrangement of the male apparatus seems like those of A. locyi Erséus, 1980, A. parviprostatus Erseús, 1980 and A. sphaeropenis Erséus and Kossmagk-Stephan, 1982. The specimen from St.13-Punta Redonda has the spherical penes devoid of distinct cuticular sheaths that characterize A. sphaeropenis, but as the spermatheca of our individual is not fully mature, we cannot verify that the particularly strong muscles around the ectal part of the spermathecal duct, characteristic of A. sphaeropenis (see Erséus and Kossmagk-Stephan 1982), will develop in the Ferrol form. A. sphaeropenis is an euryhaline species only known from intertidal sediments in North Germany.

\section{Description of new taxa}

Coralliodrilus artabrensis sp. n. Martínez-Ansemil and Caramelo.

Holotype MNCN 16.03/3045, dissected and mounted in Canada balsam.
Type locality Punta Redonda, Ria of Ferrol, Galicia, Spain, $43^{\circ} 27^{\prime} 41^{\prime \prime} \mathrm{N}, 08^{\circ} 6^{\prime} 09^{\prime \prime} \mathrm{W}$ (15 November 2000 )

Paratypes MNCN 16.03/3046-47, two specimens from type locality, stained in haematoxylin, dissected and mounted in Canada balsam.

Description (Figs. 3, 5a-c) Fixed material; no complete specimens available. Length more than $1.8 \mathrm{~mm}$, more than 17 segments. Width at XI $0.12-0.18 \mathrm{~mm}$. Prostomium roundish, about as long as wide. Secondary annulations well marked, 1-6 annuli per segment. Clitellum extending over 1/2X-XII. Somatic setae bifid, 32-49 $\mu \mathrm{m}$ long, 1.5$2.0 \mu \mathrm{m}$ thick, (3)4-5 per bundle anteriorly, (2)3-4 per bundle posterior to clitellum. Anterior setae with upper tooth slightly thinner and longer than lower, postclitellar available setae with teeth about equal in length, upper thinner than lower (Fig. 3a). Penial setae present, 4-8 per bundle, 40-48 $\mu \mathrm{m}$ long, slightly sigmoid, with a much thinner ectal part, about $1 \mu \mathrm{m}$ thick, ending in a strongly hooked tip (Figs. 3b, 5a). Male pores paired, in line with ventral setae, in posterior part of XI. Spermathecal pores paired, in lateral lines, in most anterior part of $\mathrm{X}$.

Pharyngeal glands in IV-VI. Normal alimentary system developed. Male genitalia (Figs. 3c, 5a-b) paired. Vas deferens $4-7 \mu \mathrm{m}$ wide, several times longer than atrium, strongly coiled, entering apical end of atrium; atrium small, cylindrical to ovoid, $32 \mu \mathrm{m}$ long (holotype), 16-22 $\mu \mathrm{m}$ maximum diameter, with thin outer layer of muscles and granulated and ciliated inner epithelium. Atrium terminating in a pseudopenis, 25-30 $\mu \mathrm{m}$ long, 10-20 $\mu \mathrm{m}$ wide at base, enclosed into a deep invagination of body wall. Prostate glands absent. Spermathecae (only visible in holotype; slightly damaged at dissection) with duct 20-25 $\mu \mathrm{m}$ long, maximally $13-16 \mu \mathrm{m}$ wide, and ampulla consisting of a small, almost spherical ectal part (maximally 23-25 $\mu \mathrm{m}$ wide, 25-27 $\mu \mathrm{m}$ long) prolonged into a thin-walled, narrow (about $12 \mu \mathrm{m}$ wide; incomplete, more than $12 \mu \mathrm{m}$ long) ental part. Spermathecal ampulla with loose mass of sperm (Figs. 3c, 5c).

Etymology The Latin specific epithet artabrensis refers to the Artabrian Gulf, where the ria of Ferrol is located.

Remarks The absence of prostate glands, combined with the presence of a normal alimentary system, places this new phallodriline species in the genus Coralliodrilus Erséus, 1979, as considered by Erséus (1992). The closest relative to $C$. artabrensis sp. n. appears to be the Australian $C$. parvigenitalis Erséus, 1981. The only major difference observed between the two species concerns the male ducts. The atrium of $C$. parvigenitalis is not histological bipartite and opens directly to exterior through a simple pore, without a particular copulatory sac (Erséus 1981). The atrium of C. artabrensis sp. n. ends in a well-defined projection 
Fig. 3 Coralliodrilus artabrensis sp. n. a Tips of somatic setae, free-hand drawings. a. anterior; b. segment XIII. b Tip of penial seta, free-hand drawing. c Lateral view of genital organs in segments $\mathrm{X}$ and $\mathrm{XI}$. at atrium, $p p$ pseudopenis, $p s$ penial setae, $s a$ spermathecal ampulla, $s d$ spermathecal duct, $v d$ vas deferens

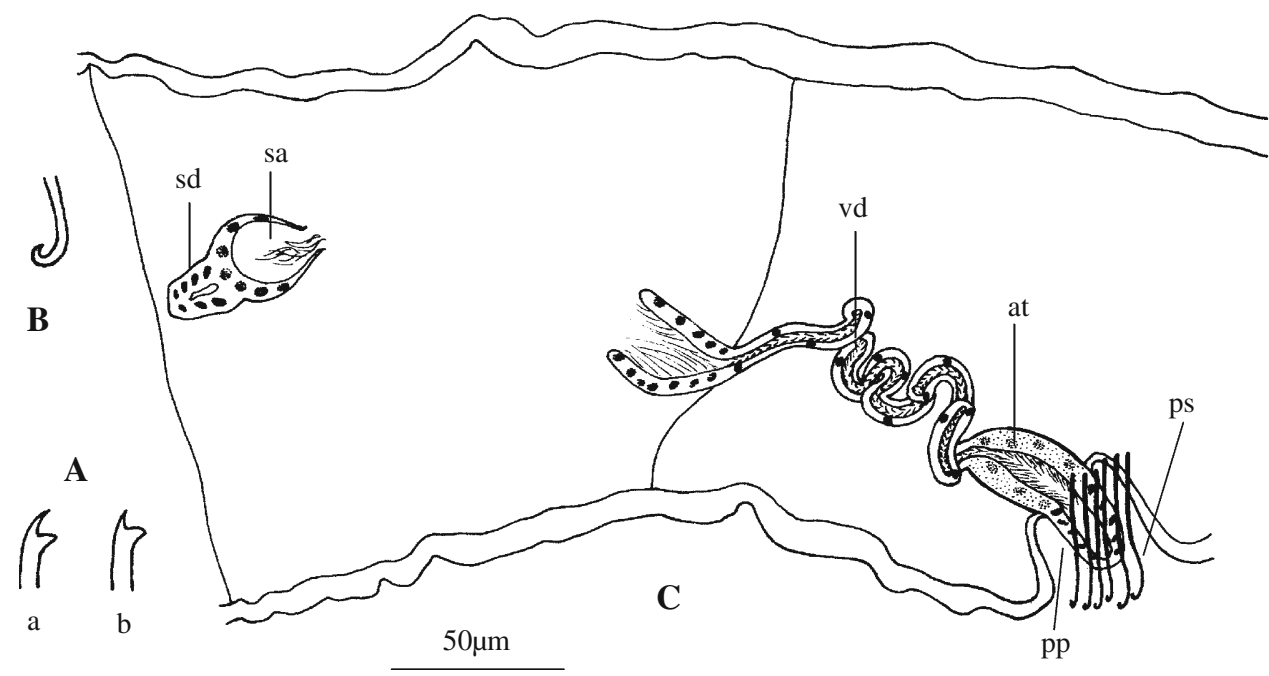

(pseudopenis) inside a copulatory sac; inner and outer parts of atrium are histologically and functionally separate. $C$. artabrensis sp. n. also shows some affinities to the Italian $C$. tyndariensis Erséus, 1982 and the Saudi Arabian C. hamatilis Erséus, 1985. The atrium of $C$. tyndariensis exhibits a clear tendency towards a bipartite histology but opens to exterior through a simple pore (Erséus 1982b). The atrium of $C$. hamatilis ends in a small protrusible projection inside a small copulatory sac, but, contrary to $C$. artabrensis $\mathrm{sp}$. $\mathrm{n}$., the atrium is folded, the spermathecal ampulla is large and sacciform, and the upper tooth of somatic setae is always shorter than lower (Erséus 1985).

Habitat Intertidal. Under mats of Fucus vesiculosus, at high water mark.

Pirodrilus fungithecatus sp. n. Martínez-Ansemil and Caramelo.

Holotype MNCN 16.03/3048, stained in haematoxylin, dissected and mounted in Canada balsam.

Type locality Punta Caleira, Ria of Ferrol, Galicia, Spain, $43^{\circ} 29^{\prime} 28^{\prime \prime} \mathrm{N}, 08^{\circ} 11^{\prime} 11^{\prime \prime} \mathrm{W}$ (31 January 2002)

Paratypes Five specimens from type locality, mounted in Canada balsam: MNCN 16.03/3048, one stained in haematoxylin and whole mounted; one unstained and whole mounted. MNCN 16.03/3049, one stained in haematoxylin and dissected; one anterior half stained in paracarmin and dissected; one anterior half unstained and whole mounted. Two specimens from Punta Redonda, Ria of Ferrol, Galicia, Spain, $43^{\circ} 27^{\prime} 41^{\prime \prime} \mathrm{N}, 08^{\circ} 16^{\prime} 09^{\prime \prime} \mathrm{W}$ (15 November 2000), stained in haematoxylin, dissected and mounted in Canada balsam: MNCN 16.03/3050.

Other material Three whole-mounted and six dissected specimens from type locality (author's collection). Other specimens from type locality were also observed alive and not preserved.
Description (Figs. 4, 5d-g) Length 1.9-3.5 mm (fixed material), 30-37 segments. Width at XI $0.15-0.25 \mathrm{~mm}$. Prostomium elongate, somewhat longer than wide. Fine particles adhering to cuticle, scattered or arranged in a more or less continuous layer over entire surface of worm. Clitellum extending over $1 / 2 \mathrm{X}$-XII. Somatic setae bifid, with upper tooth shorter and thinner than lower (Fig. 4a). Bifids 30-49 $\mu \mathrm{m}$ long, about $2 \mu \mathrm{m}$ thick, (2)3-4(5) per bundle. Ventral setae of XI modified into penial bundles, each of which contains 3-4 (exceptionally 2,5 or 6 ), straight, single-pointed setae, with somewhat curved tips, 38-48 $\mu \mathrm{m}$ long, about $2 \mu \mathrm{m}$ thick (Fig. $4 \mathrm{~b}$ ). Male pores paired, in line with ventral somatic setae, just lateral to penial setae, in posterior part of XI. Spermathecal pores paired, in line with ventral somatic setae, in most anterior part of $X$.

Pharyngeal glands in IV-VI (poorly developed in IV). Chloragogen cells from segment VI. Coelomocytes not observed. Male genitalia (Figs. 4c, 5d-f) paired. Vas deferens long (3-5 times longer than atrium), entirely ciliated, coiled, entering anterior face of atrium; ental part of vas deferens narrow (up to 4-6 $\mu \mathrm{m}$ wide) and not muscular; ectal part becoming distinctly wider and muscular (up to $8-12 \mu \mathrm{m}$ wide near the junction with atrium). Atrium small, ovoid to kidney-shaped, with a wide lumen, heavily muscular, entirely ciliated, ending in a small conical penis (16-19 $\mu \mathrm{m}$ long, 11-18 $\mu \mathrm{m}$ wide at base), enclosed in a well-distinguished penial sac; maximum with of atrium $30-43 \mu \mathrm{m}$; maximum height of atrium plus penis $35-41 \mu \mathrm{m}$. Atrium attached to ventral body wall by strong strands of muscles. Prostate glands small and compact; anterior prostate $(12-15 \mu \mathrm{m})$ located at the junction with vas deferens, attached to its basal part; posterior prostate $(13-25 \mu \mathrm{m})$ attached to middle, posterior face of atrium. Spermathecae mushroom-shaped, with a distinct rather long duct and a small ampulla (Figs. 4c, 5g). Spermathecal duct 44-62 $\mu \mathrm{m}$ long, somewhat enlarged near base (14-23 $\mu \mathrm{m}$ wide) and progressively narrowing towards ampulla (up to $7-12 \mu \mathrm{m}$ 
Fig. 4 Pirodrilus fungithecatus sp. n. a Tips of somatic setae, free-hand drawings. $a$ anterior, $b$ posterior. b Tip of penial seta, free-hand drawing. c Lateral view of genital organs in segments $\mathrm{X}$ and XI. at atrium, $m$ muscular layer, $p$ penis, $p r_{l}$ anterior prostate gland, $p r_{2}$ posterior prostate gland, $p s$ penial setae, psc penial sac, sa spermathecal ampulla, $s d$ spermathecal duct, $s m$ strands of muscles, $v d$ vas deferens

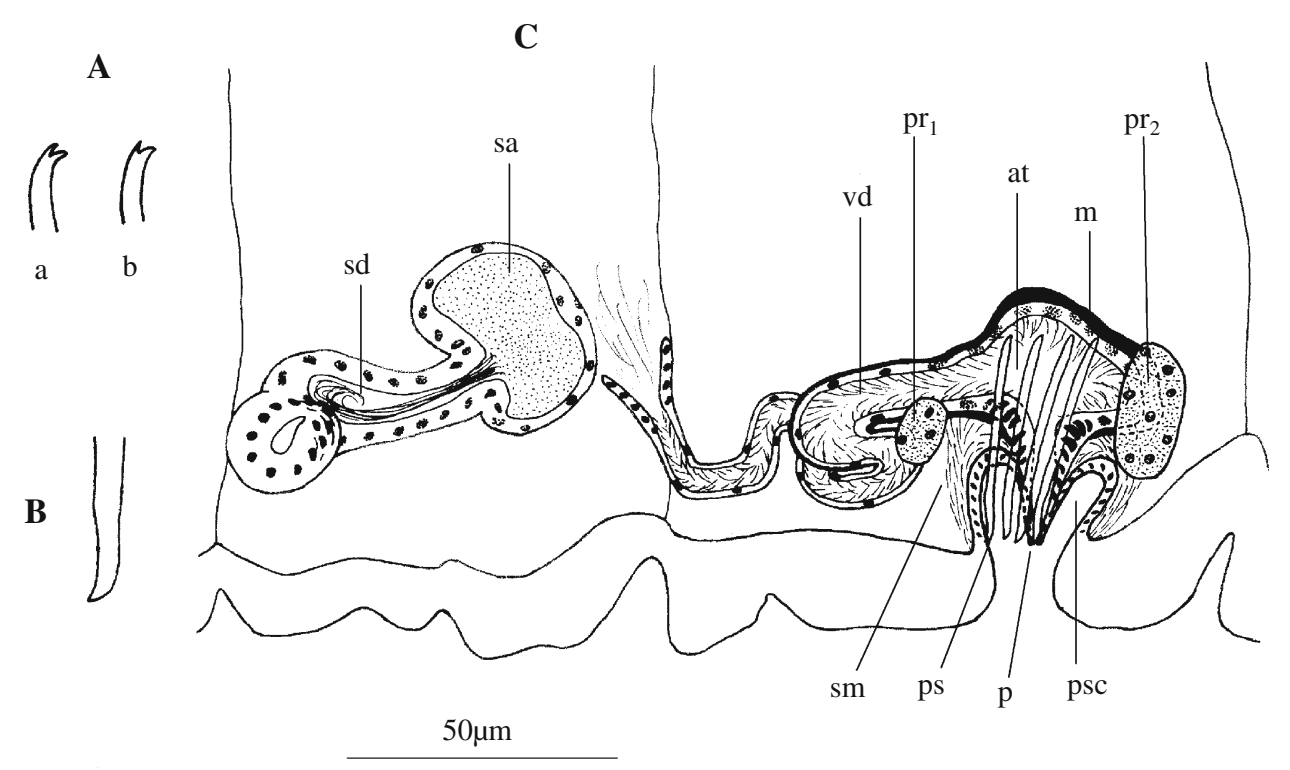

wide at junction); large lumen, especially near the base. Spermathecal ampullae $22-40 \mu \mathrm{m}$ wide. In post-copulatory specimens, ampullae filled with fine granular secretion, where a bundle of spermatozoa seem to be embedded; sperm tails can occupy an important part of spermathecal duct. Anterior and posterior seminal vesicles generally extending through IX and XI, respectively. Egg-sac generally extending through XII and XIII.

Etymology This species is named after the mushroom (=Latin "fungus") shape of the spermathecae.

Remarks The general shape of the male apparatus of this new phallodriline species suggests it could be included in the genera Pirodrilus Erséus, 1992, Pirodriloides Erséus, 1992 or Inermidrilus Erséus, 1992. All of them have small atria generally ending in plug-like papillae, and with two small compact prostate glands located more or less opposite to each other. When Erséus (1992) described Pirodrilus and Pirodriloides, he pointed out the similarities of their male apparatus; Pirodriloides was proposed separately to include Phallodrilus albanensis Erséus, 1990 because, opposite to the four species included in Pirodrilus, $P$. albanensis is devoid of penial setae and has the spermathecal pores aligned with ventral setae (spermathecal pores lateral in Pirodrilus). Moreover, the author emphasized the presence of special coelomocytes (numerous, elongated and irregular in shape) in P. albanensis, a character not shared by the recently described second species of Pirodriloides, P. breviclitellatus Erséus and Wang, 2005. As Pirodriloides, the monotypic genus Inermidrilus is also devoid of penial setae and has the spermathecal pores aligned with ventral setae, but the atria are clearly kidney-shaped and not pear-shaped as in Pirodrilus and Pirodriloides (see Erséus 1992).
The new species from the ria of Ferrol shares with Pirodrilus the presence and shape of penial setae and with Pirodriloides and Inermidrilus the position of the spermathecal pores. The shape of the atria appears to be intermediate between that of Pirodrilus or Pirodriloides (pear-shaped) and Inermidrilus (kidney-shaped). The mushroom-like shape of the spermathecae of Pirodrilus fungithecatus sp. n. is unique and quite different from that of Pirodrilus, Pirodriloides and Inermidrilus species.

The closest relative to Pirodrilus fungithecatus sp. n. are Pirodrilus minutus (Hrabě, 1973) (known from Black and North Seas), Pirodriloides albanensis (from the Albany area, southwestern Australia) and Inermidrilus georgei (Erséus, 1987) (from Scotland and Ireland). As P. minutus (see Erséus and Kossmagk-Stephan 1983), P. fungithecatus sp. n. has several simple pointed penial setae and very small atria, but opposite to $P$. minutus, $P$. fungithecatus $\mathrm{sp}$. n. has strongly muscular atrial walls and large atrial lumen. Moreover, the anterior and posterior prostate glands of $P$. minutus are similar in size (anterior very small in $P$. fungithecatus sp. n.) and the atria of $P$. minutus end in large cylindrical pseudopenes that can be easily distinguished from the small conical penes of the new species. Similar considerations as for $P$. minutus can be made while comparing the atria and prostate glands of $P$. albanensis (see Erséus 1990c) and the new species, but in P. albanensis the atria are covered with a thin but distinct muscular layer. The so-called "plug-like penial papillae" of $P$. albanensis appear to be particularly similar to the penes of $P$. fungithecatus sp. n. Although somewhat larger and curved, the atria of I. georgei (see Erséus 1987) are close to the atria of $P$. fungithecatus sp. n.; they are also provided with a thick outer layer of muscles and a wide lumen. Anterior and posterior prostate glands of I. georgei are very small and 
Fig. 5 Coralliodrilus artabrensis sp. n. a Pseudopenis. b Atrium. c Spermatheca. Pirodrilus fungithecatus sp. $\mathrm{n}$. d Penis. e Atrium. f Prostate glands and penial setae. g Spermatheca. at atrium, $p$ penis, $p p$ pseudopenis, $\mathrm{pr}_{1}$ anterior prostate gland, $p r_{2}$ posterior prostate gland, ps penial setae, $s a$ spermathecal ampulla, $s d$ spermathecal duct, $v$ de vas deferens entrance. Scale bars: $10 \mu \mathrm{m}$
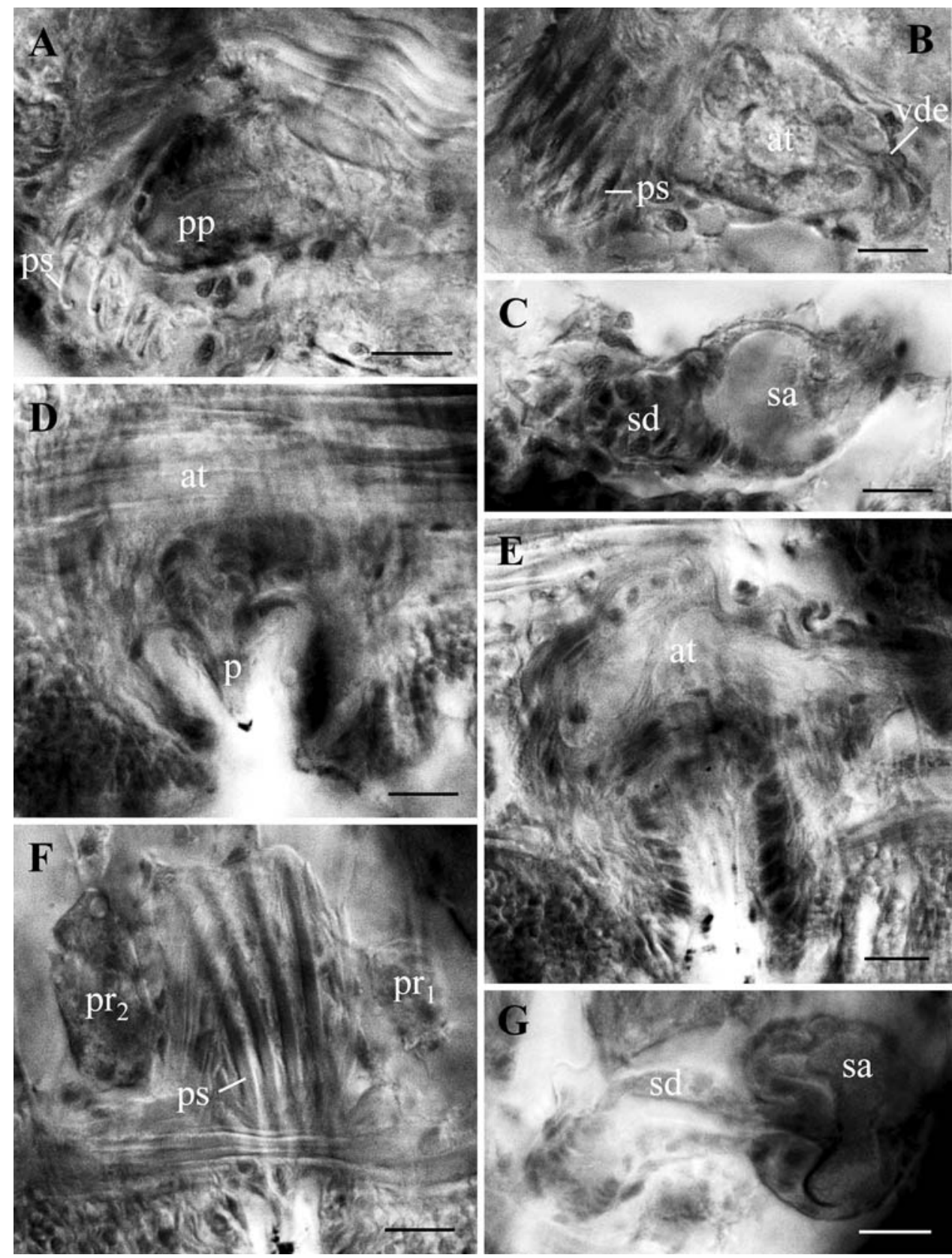

similar to the anterior prostate glands of $P$. fungithecatus sp. n. A short ectal duct leads from the lumen of each atrium to a small pseudopenial papilla in I. georgei; these papillae look simple compared to structure of the penis of $P$. fungithecatus $\mathrm{sp}$. $\mathrm{n}$. It is also interesting to note that the thick muscular lining of atria and vasa deferentia of the new species can be compared with that of Pirodrilus pinguis (Erséus, 1983) found in bathyal fine sediments from W of Brittany, France (see Erséus 1983).

Taking into account all the considerations described earlier and waiting for a probable fusion of the genus Pirodrilus and Pirodriloides, we tentatively include the new species in the genus Pirodrilus, the one that has been described first in the publication of Erséus (1992). The fusion could also affect genus Inermidrilus.

Habitat Mesolittoral, under mats of Fucus vesiculosus.

Annelid assemblages

Tables 2, 3, 4, 5, 6 show the most important quantitative data concerning the composition and structure of the annelid assemblages at the seasonally sampled stations (St. 2-Laxe; 3-Malata; 4-Caranza; 5-Caleira). An O/P index, as the ratio in terms of abundance of the two taxa, is proposed for the different sampled intertidal zones. Relevant 
Table 2 Number of families (fam.), species (spp) and individuals (ind.) in Sts. 2-5. $O$ oligochaetes, $P$ polychaetes

\begin{tabular}{lrccc}
\hline $\begin{array}{l}\text { Stations } \\
\text { (samples) }\end{array}$ & $\begin{array}{l}\text { St.2 Laxe } \\
(14)\end{array}$ & $\begin{array}{l}\text { St.3 Malata } \\
(11)\end{array}$ & $\begin{array}{l}\text { St.4 Caranza } \\
(18)\end{array}$ & $\begin{array}{l}\text { St.5 Caleira } \\
(7)\end{array}$ \\
\hline No. P fam. & 20 & 8 & 14 & 6 \\
No. O fam. & 2 & 2 & 2 & 2 \\
Total fam. & 22 & 10 & 16 & 8 \\
No. P spp & 56 & 16 & 28 & 8 \\
No. O spp & 5 & 13 & 10 & 9 \\
Total spp & 61 & 29 & 38 & 17 \\
No. P ind. & 2,476 & 237 & 5,929 & 672 \\
No. O ind. & 9 & 634 & 943 & 129 \\
Total ind. & 2,485 & 871 & 6,872 & 801 \\
\hline
\end{tabular}

Table 3 Most important data concerning the composition and structure in Station 2

\begin{tabular}{|c|c|c|c|c|}
\hline \multicolumn{5}{|l|}{ Station 2 Laxe } \\
\hline Zone (samples) & Bif (3) & Fse (6) & Myt (6) & Fve (2) \\
\hline No. fam. & 14 & 18 & 10 & 11 \\
\hline No. spp & 24 & 49 & 15 & 17 \\
\hline Density (ind m ${ }^{-2}$ ) & 6,658 & 6,037 & 367 & 1,862 \\
\hline $\mathrm{O} / \mathrm{P}$ ratio & 0 & 0.003 & 0.045 & 0.007 \\
\hline \multicolumn{5}{|l|}{ Dominant fam. $(\geq 20 \%)$} \\
\hline Spionidae & & 26.0 & & 24.2 \\
\hline Cirratulidae & & & & 22.8 \\
\hline Syllidae & 49.9 & & 35.2 & \\
\hline Nereidae & & & & 22.8 \\
\hline Sabellidae & & 24.6 & & \\
\hline \multicolumn{5}{|l|}{ Dominant $\operatorname{spp}(\geq 10 \%)$} \\
\hline Malacoceros tetraceros & & & 11.4 & \\
\hline Polydora ciliata & & 11.8 & & 14.1 \\
\hline Cirratulus cirratus & & & 19.3 & \\
\hline Cirratulus chrysoderma & & 10.2 & & 22.8 \\
\hline Syllis vittata & & & 32.9 & \\
\hline Sphaerosyllis pirifera & 12.9 & & & \\
\hline Exogone naidina & 34.5 & & & \\
\hline Platynereis dumerilii & 18.1 & 12.9 & & 22.1 \\
\hline Fabricia stellaris & & 10.6 & & \\
\hline Amphiglena mediterranea & 13.6 & 13.8 & & \\
\hline
\end{tabular}

Abbreviations as in Table 2

differences concerning both species' richness, density, $\mathrm{O} / \mathrm{P}$ index and dominant taxa in each locality were observed and will be presented and discussed in the following.

The polychaete family Spirorbidae was not taken into account due to its sessile mode of life and gregarious mode of larval settlement (Knight-Jones et al. 1971, 1975). A previous study of this family in this ria (Parapar et al. 1994b) revealed that four species were present in the area. Spirorbis inornatus L'Hardy and Quiévreux is the most abundant,
Table 4 Most important data concerning the composition and structure in Station 3

\begin{tabular}{llll}
\hline Station 3 Malata & & & \\
\hline Zone (samples) & Fsp (1) & FveM (6) & FspM (4) \\
\hline No. fam. & 4 & 10 & 9 \\
No. spp & 6 & 22 & 16 \\
Density (ind m ${ }^{-2}$ ) & 300 & 2,429 & 1,725 \\
O/P ratio & 2.000 & 3.318 & 1.816 \\
Dominant fam. ( $\geq 20 \%)$ & & & \\
Enchytraeidae & & & 38.4 \\
Naididae & 66.7 & 63.6 & 26.1 \\
Dominant spp ( $\geq 10 \%)$ & & & \\
$\quad \begin{array}{l}\text { Perinereis oliveirae } \\
\text { Fabricia stellaris }\end{array}$ & 16.7 & & 10.5 \\
Lumbricillus. cf. lineatus & & & 37.3 \\
Tubificoides benedii & & 32.1 & 16.7 \\
$\begin{array}{l}\text { Gianius } \text { sp. } \\
\text { Tectidrilus sp. } \\
\text { Tubificinae immat. }\end{array}$ & 16.7 & & \\
Limnodriloidinae immat. & 25.0 & & \\
\hline Abbreviaions in Table 2.6 & & \\
\hline
\end{tabular}

Abbreviations as in Table 2

S. spirorbis (L.) is dominant in upper mesolittoral levels, $S$. corallinae De Silva and Knight-Jones is usually present on the red alga Corallina elongata J. Ellis and Solander in the lower shore, and S. tridentatus Levinsen is restricted to one locality at the channel of the ria.

The total abundance of many oligochaete species was estimated considering the mature/immature ratio, as generally immature oligochaetes cannot be identified to the species level.

\section{Discussion}

The study revealed a high annelid diversity in the intertidal rocky shores of the ria of Ferrol. The 14,619 specimens collected represent at least 94 species belonging to 24 polychaete (11,585 individuals, 76 species) and 2 oligochaete families (3,034 individuals, 18 species, at least 2 of them new to science) (Table 1).

All the polychaete species found were already recorded from the ria of Ferrol, in several studies devoted to this group, mostly in 1990s (e.g. Besteiro et al. 1987; Parapar et al. 1992a, 1993b, 1993c, 1994a, 1995). The species richness of polychaetes in the rocky intertidal zone of the ria is rather high compared to that found in similar habitats of other estuaries on the European boreo-arctic coasts (Oug 2001; Ingólfsson 1996, 2006; Saier 2002), but similar compared to the results obtained at similar latitudes (Giangrande et al. 2004; Laborda et al. 1991). This high 
Table 5 Most important data concerning the composition and structure in Station 4

\begin{tabular}{|c|c|c|c|c|c|}
\hline \multicolumn{6}{|l|}{ Station 4 Caranza } \\
\hline Zone (samples) & Fve (2) & Fse (2) & FveM (4) & FseM (4) & Fsp (6) \\
\hline No. fam. & 8 & 8 & 11 & 12 & 7 \\
\hline No. spp & 11 & 11 & 19 & 21 & 14 \\
\hline Density (ind $\mathrm{m}^{-2}$ ) & 987 & 2,287 & 3,687 & 3,618 & 23,087 \\
\hline $\mathrm{O} / \mathrm{P}$ ratio & 0.145 & 0.452 & 0.055 & 0.007 & 0.183 \\
\hline \multicolumn{6}{|l|}{ Dominant fam. $(\geq 20 \%)$} \\
\hline Spionidae & 44.3 & 54.1 & 28.0 & 34.7 & \\
\hline Syllidae & & & & 22.5 & \\
\hline Sabellidae & & & 34.1 & 29.0 & 83.7 \\
\hline Naididae & & 31.1 & & & \\
\hline \multicolumn{6}{|l|}{ Dominant spp $(\geq 10 \%)$} \\
\hline Polydora ciliata & 34.38 & 57.99 & 26.62 & 33.85 & \\
\hline Capitella capitata & 11.46 & & 11.53 & & \\
\hline Odontosyllis ctenostoma & & & & 15.04 & \\
\hline Fabricia stellaris & & & 32.63 & 28.72 & 77.59 \\
\hline Marionina macgrathi & & & & & 14.42 \\
\hline Lumbricillus cf. lineatus & 12.5 & 19.53 & & & \\
\hline
\end{tabular}

Table 6 Most important data concerning the composition and structure in Station 5

\begin{tabular}{llll}
\hline Station 5 Caleira & & & \\
\hline Zone (samples) & Asc (1) & Fve (2) & FveM (4) \\
\hline No. fam. & 3 & 5 & 8 \\
No. spp & 3 & 6 & 16 \\
Density (ind ${ }^{-2}$ ) & 250 & 875 & 4,456 \\
O/P ratio & 0 & 2.900 & 0.111 \\
Dominant fam. ( $\geq 20 \%)$ & & & \\
Spionidae & & & 29.7 \\
Sabellidae & 80.0 & & 56.2 \\
Naididae & & 74.4 & \\
Dominant spp ( $\geq 10 \%)$ & & & \\
Polydora ciliata & & 15.73 & 29.82 \\
Fabricia stellaris & 80 & & 56.4 \\
Marionina macgrathi & & 34.18 & \\
Marionina appendiculata & & 13.15 & \\
Tubificoides benedii & & 14.61 & \\
\hline Abrevitions as & & &
\end{tabular}

Abbreviations as in Table 2

diversity could be explained by several factors, such as the emplacement of the ria, in the boundary between the Eastern Atlantic boreal region and the Mediterranean-Atlantic region, the diverse degree of exposure of the sampling localities, and the high number of different microhabitats in each of them, including the high amount of muddy sediments at the lower shore levels in the sheltered localities.

Our data concerning the oligochaetes can be only roughly compared with the complete study by Healy (1996a) on the distribution of this group on an exposed rocky shore in southeast Ireland. In this work, a total of 12 species were identified, with a high percentage of species new to science or new to the area. Our results reinforce the view of this author that many novelties are to be expected in oligochaete communities of rocky shores.

The joint analysis of the polychaete and oligochaete fauna identified to species level in the ria of Ferrol allows some general ecological considerations concerning the ria as a whole, and, in particular, the composition and structure of the communities in the more intensively sampled stations.

Although only four stations were sampled intensively, and taking into account that local environmental conditions can deeply determine the composition and structure of the annelid communities, our overall data suggests that intertidal specific richness increases from the inner to the outer part of the ria. This general trend has already been observed in other studies on similar estuaries, but those were devoted exclusively to the polychaete fauna (Oug 2001) or dealt with the entire invertebrate community (García-Alvarez et al. 1993).

In general terms, polychaetes are more diversified and abundant in the outer semi-exposed stations, while oligochaetes are so in the inner sheltered ones. No annelids were found in the samples taken at the innermost station (St.7-Xubia, F. ceranoides zone). The most frequent and most widely distributed species was Polydora ciliata, which was found in most of the samples taken, apart from the inner (St.7-Xubia) and outer ones (St.1-Fornelos). It is a well-known euriecious opportunistic spionid that 
can proliferate in organically enriched and reduced sediments (Pearson and Rosenberg 1978; Villalba and Viéitez 1985; Grall and Glémarec 1997; Çinar et al. 2005).

Stations 2, 3, 4 and 5 show marked differences in annelid composition. The most oceanic station, St.2-Laxe (Fig. 2; Tables 2, 3), with a semi-exposed condition, is the richest in terms of species (61), with the highest number of polychaete species in the area but the lowest number of oligochaete species (56 and 5, respectively). Syllids, with 12 species identified, is the most diversified and dominant polychaete group at this station, reaching around 50\% of the total abundance in the Bifurcaria zone, and 35\% in that of Mytilus. Ten polychaete species (three syllids, two spionids, two cirratulids, two sabellids, and one nereidid) each represents more than $10 \%$ of the annelid community in their respective zones. In contrast, the most abundant oligochaete population reaches only around 2\% in the Mytilus zone. The highest $\mathrm{O} / \mathrm{P}$ value obtained at this station was 0.045 in the Mytilus zone. According to Giangrande et al. (2005), syllids respond rapidly to an environmental disturbance. Most of the other dominant species (like Polydora ciliata, Cirratulus cirratus, C. chrysoderma and Platynereis dumerilii) are characteristically tolerant to organic enrichment or may even proliferate in reduced sediments (Grall and Glémarec 1997; Borja et al. 2000; Bellan 1984; Bellan et al. 1988).

The situation in St.3-Malata (Fig. 2; Tables 2, 4) is quite different. This station is located at the inner part of a semiclosed bay in the middle of the ria (Fig. 1), with the lowest tide levels characterized by muddy sediment. At this station, the annelid community was clearly dominated by oligochaetes in terms of abundance $(\mathrm{O} / \mathrm{P}=1.8-3.3)$, but the specific richness observed was similar for both groups of annelids (16 polychaetes and 13 oligochaetes, respectively). This, together with the dominance of the naidid $T$. benedii, the enchytraeid $L$. cf. lineatus and, to a lesser degree, the abundance of the capitellid $C$. capitata complex suggests that this locality may be regarded as a disturbed environment. In fact, $T$. benedii is considered as one of the most successful inhabitants of hypoxic/sulfidic sediments in European estuaries (Giere and Pfannkuche 1982; Giere et al. 1999); L. lineatus is a well-known resistant intertidal form, able to endure the impact of pulp mill effluents and high concentrations of hydrocarbon (Coates and Ellis 1980; Giere and Pfannkuche 1982); and the C. capitata complex is a well-known indicator of organically enriched sediments (Tsutsumi 1990; Pocklington and Wells 1992), which can proliferate even in sediments reduced up to the surface (Giere et al. 1999).

The annelid community of St.4-Caranza (Fig. 2; Tables 2, 5) is composed of a comparatively diverse assemblage of annelids, made up by common and well-known species (28 polychaetes, 10 oligochaetes). Among these, the most abundant taxa found in the ria of Ferrol, i.e. the sabellid Fabricia stellaris and the spionid P. ciliata, were dominant in all the sampled zones of this locality, sharing dominance at the middle intertidal level, while $F$. stellaris dominated in the upper intertidal and $P$. ciliata in the lower one. Caranza was the only place where the population of the commonly widespread naidid $P$. litoralis was relatively abundant. The highest value of $\mathrm{O} / \mathrm{P}$ observed in this station was 0.45 , in the $F$. serratus zone. The composition and structure in the oligochaete community observed in this sheltered station of the middle part of the ria, would reveal environmental conditions not strongly disturbed (Giere and Pfannkuche 1982). The high densities of $F$. stellaris and the enchytraeid Marionina macgrathi in the $F$. spiralis zone ( $F$. stellaris density $>23.000$ ind $\mathrm{m}^{-2}$ ), representing both species, more than $92 \%$ of the total annelid abundance observed, are worth mentioning. In this particular zone, the enchytraeids show the highest density values in the ria and seem to reach the highest number of species with at least five taxa present. This seems to be related to the presence of an algal turf of Ceramium gaditanum (Clemente) Cremades and Gelidium pusillum (Stackhouse) Le Jolis under the mats of $F$. spiralis which could serve, in some way, as shelter or food supply as was previously proposed by several authors for other species of enchytraeids (see Giere and Pfannkuche 1982). Moreover, the high surface/volume ratio provided by both species of algae, along with the resulting retention of high amounts of fine sediments would contribute to increase the spatial complexity of this peculiar environment (Cremades pers. com.).

Station 5-Caleira (Fig. 2, Tables 2, 6), located in the inner part of the ria, with only eight species of polychaetes and nine species of oligochaetes identified, shows the most poorly diversified annelid community. This community is composed of common species widely distributed all along the ria (mainly P. ciliata, F. stellaris and $T$. benedii) and by species restricted or mainly found in the inner part of the ria (namely two species of small oligochaetes, the naidid P. fungithecatus $\mathrm{sp} . \mathrm{n}$. and the enchytraeid M. macgrathi). Although only two samples were taken in the $F$. vesiculosus zone, and four in a bed of $F$. vesiculosus with Mytilus, some aspects deserve to be emphasized: the overall low number of annelid species, and the high dominance of oligochaetes (only naidids) in the former zone (6 species; $\mathrm{O} / \mathrm{P}=2.9$ ), while in the latter the specific richness is higher and polychaetes dominate $(16$ species; $\mathrm{O} / \mathrm{P}=0.11)$. A similar trend was also observed in St.4 and could be related to the increase of spatial complexity represented by the mussel bed in the Fucus zone, which provides shelter and sedimentary microhabitats occupied by a multitude of small invertebrates (Giere and Pfannkuche 1982; Günther 1996; Svane and Setyobudiandi 1996; Elías et al. 2003; Surugiu 
2005). This seems to be especially noticeable for St.5, where the finest fraction of the sediment $(<63 \mu \mathrm{m})$ reaches about $20 \%$, as a consequence of the anti-clockwise tidal circulation that provides an intense deposition of fine particles in the northern shoreline of the ria of Ferrol (Cobelo-García and Prego 2004).

According to Díaz (1980), "in areas where pollution or other physical factors result in extreme environmental conditions or reduced habitat diversity, estuarine oligochaetes tend to become more important through an increase in density and a reduction in polychaete species that are able to tolerate the extreme conditions". Our results in the ria of Ferrol seem to confirm this explanatory model. Given that the resulting $\mathrm{O} / \mathrm{P}$ ratio values support this panorama, we propose this ratio as a useful tool to outline general environmental conditions in intertidal rocky shores based on annelid abundance values.

Many previously proposed biological indices to evaluate environmental quality face the limitation of the necessity of taxonomic skills (see Simboura and Zenetos 2002; Díaz et al. 2004), but others, such as the oligochaete/chironomid ratio used for lake monitoring (Wiederholm 1980), the nematode/copepod ratio used in marine sediment monitoring (Raffaeli and Mason 1981; Warwick 1981; Raffaeli 1987), and the O/P ratio proposed here to evaluate environmental conditions in intertidal rocky shores, have the advantage of not requiring taxonomic expertise, which is scarce nowadays. At any rate, the use of the $\mathrm{O} / \mathrm{P}$ ratio has to be taken as a rough first tool, which by no way replaces accurate studies at the population level.

On the other hand, the detailed catalogue of rocky intertidal annelid species presented in this study is peculiar in addressing the annelid community as a whole, giving high relevance to the taxonomic accuracy in the identification of the species. Nevertheless, many of the widely cited 'indicator species' in environmental assessments should be used with caution, because their taxonomic and biological variability suggests 'species' mixtures or complexes. Thus, Parker (1991) states that 'true species buried within the taxonomic complexes may respond quite differently to environmental stresses, and their indicator value may vary substantially'. At any rate, this limitation in the usefulness of particular key-species in biomonitoring studies does not reduce the importance of local faunistic cataloguing, especially in intertidal areas highly sensitive to acute or chronic pollution events.

Intense tanker traffic makes the Galician coastline highly susceptible for acute pollution events like oil spills, given that the coasts become the final depository of the fuel. In the past three decades, several oil spills have occurred in this shore, with the Prestige tanker oil spill in November 2002 as the most recent one. In areas such as the Galician coasts, that are permanently endangered by catastrophic events, the availability of pre-impact data would permit to conclude the oil spill responsibility of any presumed change in the environment (Forde 2002). At the same time, however, one must always take into account that the analysed communities also change over time and may exhibit important inter-annual variations (Page et al. 1995; Wiens and Parker 1995).

Acknowledgments This work was supported by the Xunta de Galicia (Project No. CGL2004-04680-C10-02) and by the Spanish Ministry of Education and Science and FEDER (Project No. CGL.2006-13417). The authors wish to thank J. Cremades (Univ. of A Coruña), I. Jirkov (Moscow State Univ.) and D. Eibye-Jacobsen (ZMUC) for helpful advice concerning different issues of this work. S. Cuadrado helped in field sampling and technical assistance, N. Sánchez and E. Couñago (Univ. A Coruña) prepared the map, J. Moreira (Univ. of Santiago) provided comments on an early version of the manuscript and J. García-Carracedo revised the English version. Senior author (JP) gratefully acknowledges SYNTHESYS support made available by the European Community-Research Infrastructure Action under the FP6 Structuring the European Research Area (Project DK-TAF-3118). Two anonymous referees greatly improved the quality of the paper.

\section{References}

Alós C (2004) Familia Phyllodocidae Örsted, 1843. In: Viéitez JM, Alós C, Parapar J, Besteiro C, Moreira J, Núñez J, Laborda J, San Martín G. Annelida, Polychaeta I. Ramos MA et al (eds) Fauna Ibérica, vol 25. Museo Nacional de Ciencias Naturales CSIC, Madrid, pp 105-209

Barreiro-Lozano R, Carballeira-Ocaña A, Real-Rodríguez C (1988) Metales pesados en los sedimentos de cinco sistemas de ría (Ferrol, Burgo, Arousa, Pontevedra y Vigo). Thalassas 6:61-70

Bellan G (1984) Indicateurs et indices biologiques dans le domaine marin. Bull Ecol 15:13-20

Bellan G, Desrosiers G, Willsie A (1988) Use of an annelid pollution index for monitoring a moderately polluted littoral zone. Mar Pollut Bull 19:662-665

Besteiro C, Urgorri V, Parapar J (1987) Aportaciones nuevas para la fauna ibérica: Anélidos Poliquetos. Cah Biol Mar 28:491-504

Bonse S, Schmidt H, Eibye-Jacobsen D, Westheide W (1996) Eulalia viridis (Polychaeta: Phyllodocidae) is a complex of two species in northern Europe: results from biochemical and morphological analyses. Cah Biol Mar 37:33-48

Borja A, Franco J, Pérez V (2000) A marine biotic index to establish the ecological quality of soft-bottom benthos within European estuarine and coastal environments. Mar Pollut Bull 40:1100-1114

Çinar ME, Ergen Z, Dagli E, Petersen ME (2005) Alien species of spionid polychaetes (Streblospio gynobranchiata and Polydora cornuta) in Izmir Bay, Eastern Mediterranean. J Mar Biol Ass UK $85: 821-827$

Coates K, Ellis DV (1980) Enchytraeid oligochaetes as marine pollution indicators. Mar Pollut Bull 11:171-174

Cobelo-García A, Prego R (2004) Influence of point sources on trace metal contamination and distribution in a semi-enclosed industrial embayment: the Ferrol Ría (NW Spain). Estuar Coast Shelf Sci 60:695-703

Currás A, Mora J (1991) Comunidades bentónicas de la ría del Eo (Galicia-Asturias, NW España). Cah Biol Mar 32:57-81

Díaz RJ (1980) Ecology of tidal freshwater and estuarine Tubificidae (Oligochaeta). In: Brinkhurst RO, Cook DG (eds) Aquatic oligochaete biology. Plenum Press, New York, pp 319-330 
Díaz RJ, Solan M, Valente RM (2004) A review of approaches for classifying benthic habitats and evaluating habitat quality. J Environ Manag 73:165-191

Elías R, Rivero MS, Vallarino EA (2003) Sewage impact in the composition and distribution of the polychaeta associated to intertidal mussel beds of the Mar del Plata rocky shore, Argentina. Iheringia Sér Zool 93:309-318

Erséus C (1981) Taxonomic studies of Phalladrilinae (Oligochaeta, Tubificidae) from the Great Barrier Reef and the Comoro Islands with descriptions of ten new species and one new genus. Zool Scr 10:15-31

Erséus C (1982a) Taxonomic revision of the marine genus Limnodriloides (Oligochaeta: Tubificidae). Verh Naturwiss Ver Hamburg (NF) 25:207-277

Erséus C (1982b) Three new species of the marine genus Coralliodrilus (Oligochaeta, Tubificidae) from Italy. Boll Zool 49:241-247

Erséus C (1983) Deep-sea Phallodrilus and Bathydrilus (Oligochaeta, Tubificidae) from the Atlantic Ocean, with the descriptions of ten species. Cah Biol Mar 24:125-146

Erséus C (1985) Annelida of Saudi Arabia. Marine Tubificidae (Oligochaeta) of the Arabian Gulf coast of Saudi Arabia. Fauna Saudi Arabia 6 (1984), pp 130-154

Erséus C (1987) Seven new marine species of Phallodrilus (Oligochaeta: Tubificidae) from various parts of Europe, and a re-examination of the type species $P$. parthenopaeus Pierantoni. J Nat Hist 21:915-931

Erséus C (1990a) Marine oligochaeta of Hong Kong. In: Morton B (ed) Proceedings of the second international marine biological workshop: The marine flora and fauna of Hong Kong and Southern China, Hong Kong 1986. Hong Kong University Press, Hong Kong, pp 259-335

Erséus C (1990b) The marine Tubificidae (Oligochaeta) of the barrier reef ecosystems at Carrie Bow Bay, Belize, and other parts of the Caribbean Sea, with descriptions of twenty-seven new species and revision of Heterodrilus, Thalassodrilides and Smithsonidrilus. Zool Scr 19:243-303

Erséus C (1990c) The marine Tubificidae and Naididae (Oligochaeta) of South-Western Australia. In: Wells FE, Walker DI, Kirkman $\mathrm{H}$, Lethbridge $\mathrm{R}$ (eds) Proceedings of the third international marine biological workshop: The marine flora and fauna of Albany, Western Australia. Western Australian Museum, Perth, vol 1, pp 43-88

Erséus C (1992) A generic revision of the Phallodrilinae (Oligochaeta: Tubificidae). Zool Scr 21:5-48

Erséus C (2002) Mangroves and marine oligochaete diversity. Wetl Ecol Manag 10:197-202

Erséus C, Kossmagk-Stephan KJ (1982) A new species of Aktedrilus (Oligochaeta, Tubificidae) from the North Sea coast of the Federal Republic of Germany. Zool Anz Jena 209:91-96

Erséus C, Kossmagk-Stephan KJ (1983) Redescription of Phallodrilus minutus (Oligochaeta, Tubificidae) based on mew material from the North Sea coast of Germany. Sarsia 68:229-231

Erséus C, Wang HZ (2005) Marine Tubificidae (Annelida: Clitellata) of the Esperance Area, Western Australia, Australia. In: Well FE, Walker DI, Jones DS (eds) The marine flora and fauna of Esperance Area, Western Australia. Western Australia Museum, Perth, pp 399-424

Erséus C, Wetzel MJ, Gustavsson L (2008) ICZN rules-a farewell to Tubificidae (Annelida, Clitellata). Zootaxa 1744:66-68

Forde SE (2002) Modelling the effects of an oil spill on open populations of intertidal invertebrates. J Appl Ecol 39:595-604

García-Alvarez O, Míguez-Rodríguez L, Fernández-Abelleira J, OrtizDelgado S, Veloso-Ríos M (1993) Poblamientos faunísticos intermareales de sustrato duro en la ría de A Coruña. Publ Espec Inst Español Oceanogr 11:267-274
Giangrande A, Delos AL, Musco L, Licciano M, Pierre C (2004) Polychaete assemblages of rocky shore along the South Adriatic coast (Mediterranean Sea). Cah Biol Mar 45:85-95

Giangrande A, Licciano M, Musco L (2005) Polychaetes as environmental indicators revisited. Mar Pollut Bull 50:1153-1162

Giere O (1971) Marionina spicula-ein ökologisch und morphologisch spezialisierter mariner Enchytraeide (Oligochaeta). Helgoländer wiss Meeresunters 22:350-361

Giere O (1979) The impact of oil pollution on intertidal meiofauna. Field studies after the La Coruña-spill. May 1976. Cah Biol Mar 20:231-251

Giere O (2006) Ecology and biology of marine oligochaeta-an inventory rather than another review. Hydrobiologia 564:103-116

Giere O, Pfannkuche O (1982) Biology and ecology of marine Oligochaeta. A review. Oceanogr Marine Biol Annu Rev 20:173-308

Giere O, Preusse JH, Dubilier N (1999) Tubificoides benedii (Tubificidae, Oligochaeta) - a pioneer in hypoxic and sulfidic environments. An overview of adaptative pathways. Hydrobiologia 406:235-241

Grall J, Glémarec M (1997) Using biotic indices to estimate macrobenthic community perturbations in the Bay of Brest. Estuar Coast Shelf Sci 44:43-53

Granja A, Cremades J, Bárbara I (1992) Catálogo de las algas bentónicas marinas de la ría de Ferrol (Galicia N.O. de la Península Ibérica) y consideraciones biogeográficas sobre su flora. NACC (Biol) 3:3-21

Graña-Carrodeguas J, Macías F (1987) Evaluación de parámetros ambientales en la ría de Ferrol. Cuad Marisq Publ Téc 9:223-231

Günther CP (1996) Development of small Mytilus beds and its effects on resident intertidal macrofauna. PSZNI Mar Ecol 17:117-130

Healy B (1996a) The distribution of Oligochaeta on an exposed rocky shore in southeast Ireland. Hydrobiologia 334:51-62

Healy B (1996b) New species of Marionina (Oligochaeta: Enchytraeidae) from a wave-exposed rocky shore in SE Ireland. J Nat Hist 30:1287-1295

Ingólfsson A (1996) The distribution of intertidal macrofauna on the coast of Iceland in relation to temperature. Sarsia 81:29-44

Ingólfsson A (2006) The intertidal seashore of Iceland and its animal communities. Zool Iceland I 7:1-85

International Commission of Zoological Nomenclature [ICZN] (2007) Opinion 2167 (Case 3305) Naididae Ehrenberg, 1828 (Annelida, Clitellata): precedence over Tubificidae Vejdovský, 1876 maintained. Bull Zool Nomencl 64:71-72

Knight-Jones EW, Bailey JH, Isaac MJ (1971) Choice of algae by larvae of Spirorbis, particularly of Spirorbis spirorbis. In: Proc 4th Eur Mar Biol Symp, pp 89-104

Knight-Jones EW, Knight-Jones P, Al-Ogily SM (1975) Ecological isolation on the Spirorbidae. In: Proc 9th Eur Mar Biol Symp, pp 539-561

Laborda AJ, Cimas E, Marcilla I (1991) Influencia de la contaminación en la distribución de los anélidos poliquetos de sustrato rocoso intermareal de la region de Cabo Peñas (Asturias, España). Bol Inst Esp Oceanogr 7:75-90

López-Jamar E (1978) Macrobentos infaunal de la Ría de Pontevedra. Bol Inst Esp Oceanogr 4:111-130

López-Jamar E (1982) Distribución espacial de las comunidades bentónicas infaunales de la Ría de Arosa. Bol Inst Esp Oceanogr 7:255-268

López-Jamar E, Francesch O, Dorrío AV, Parra S (1995) Long-term variation of the infaunal benthos of La Coruña Bay (NW Spain): results from a 12-year study (1982-1993). Sci Mar 59:49-61

Martínez-Ansemil E (1982) Les oligochètes aquatiques de la péninsule Ibérique ( $2^{\circ}$ note) avec la description de Lumbricillus brunoi $\mathrm{n}$. sp. (Enchytraeidae). Bull Soc Hist Nat Toulouse 118:145-151

Martínez-Ansemil E (1984) Oligoquetos dulceacuícolas de Galicia: catálogo y diversos aspectos ecológicos. Limnetica 1:311-320 
Martínez-Ansemil E (1990) Etude biologique et écologique sur les oligochètes aquatiques de la rivière Tambre et ses milieux associés (Galice, Espagne). Ann Limnol 26:131-151

Martínez-Ansemil E (1993) Etudes sur les oligochètes aquatiques des pays du pourtour de la Méditerranée: taxonomie, phylogénie, biogéographie et écologie. Thèse d'Etat (Sciences). Université Paul Sabatier, Toulouse

Martínez-Ansemil E, Giani N (1980) Premières données sur les oligochètes aquatiques de la péninsule Ibérique. Ann Limnol 16:4354

Martínez-Ansemil E, Giani N (1987) Une nouvelle espèce marine de Tubificidae (Oligochaeta) d'Espagne: Tubificoides galiciensis $\mathrm{n}$. sp. Vie Milieu 37:53-58

McCann LD, Levin LA (1989) Oligochaete influence on settlement, growth and reproduction in a surface-deposit-feeding polychaete. J Exp Mar Biol Ecol 131:233-253

Mora J, García MA, Acuña R (1982) Contribución al conocimiento de las poblaciones de la macrofauna bentónica de la ría de Pontevedra. Oecol Aquat 6:51-56

Nielsen CO, Christensen B (1959) The Enchytraeidae. Critical revision and taxonomy of European species (Studies on Enchytraeidae VII). Natura Jutlandica 8(9):1-160

Oug E (2001) Polychaetes in intertidal rocky and sedimentary habitats in the region of Troms $\varnothing$, northern Norway. Sarsia 86:75-83

Page DS, Gilfillan ES, Boehm PD, Harner EJ (1995) Shoreline ecology program for Prince William Sound, Alaska, following the Exxon Valdez oil spill: Part 1-study design and methods. In: Well G, Butler JN, Hughes JS (eds) Exxon Valdez Oil Spill: fate and effects in Alaskan Waters, ASTM STP 1219. American Society for Testing and Materials, Philadelphia, pp 263-265

Parapar J (1991) Anélidos Poliquetos bentónicos de la ría de Ferrol. $\mathrm{PhD}$ Thesis. University of Santiago de Compostela, Spain

Parapar J, Besteiro C, Urgorri V (1992a) Nuevas aportaciones al conocimiento de los anélidos poliquetos en el litoral gallego (N. O. Península Ibérica). NACC (Biol) 3:109-123

Parapar J, Besteiro C, Urgorri V (1992b) Primera cita para la Península Ibérica de Harmothoe marphysae McIntosh, 1876 y de Harmothoe andreapolis McIntosh, 1874 (Polychaeta, Polynoidae). Bol Inst Esp Oceanogr 8:311-316

Parapar J, Besteiro C, Urgorri V (1993a) Primera cita de Ampharete finmarchica (Sars, 1865) (Polychaeta: Ampharetidae) en el litoral de la península Ibérica. Bol Inst Esp Oceanogr 9:367-372

Parapar J, Besteiro C, Urgorri V (1993b) Aportaciones a la taxonomía y autoecología de los anélidos de la Península Ibérica: poliquetos de la ría de Ferrol. Cah Biol Mar 34:411-432

Parapar J, Freire J, Urgorri V, Besteiro C (1993c) Morphological variability in Eunice vittata (Chiaje, 1828) (Polychaeta; Eunicidae) in the ria de Ferrol (Galicia, NW Spain). Ophelia 37:117-125

Parapar J, O'Connor B, Besteiro C, Urgorri V (1994a) Abyssoninoe hibernica (McIntosh) (Polychaeta, Lumbrineridae) a valid species from the northeast Atlantic. Sarsia 79:157-162

Parapar J, Besteiro C, Urgorri V, Troncoso J (1994b) Aportaciones al género Spirorbis Daudin, 1800 (Annelida, Polychaeta) en la Península Ibérica. Bol R Soc Esp Hist Nat (Biol) 91:41-48

Parapar J, Besteiro C, Urgorri V (1995) Consideraciones a la taxonomía y autoecología de algunas especies de anélidos poliquetos ibéricos. Thalassas 11:105-125
Parker T (1991) Pollution indicator species. Mar Pollut Bull 22:101-102

Pearson TH, Rosenberg R (1978) Macrobenthic succession in relation to organic enrichment and pollution of the marine environment. Oceanogr Mar Biol Annu Rev 16:229-311

Pocklington P, Wells PG (1992) Polychaetes. Key taxa for marine environmental quality monitoring. Mar Pollut Bull 24:593-598

Raffaeli DG (1987) The behaviour of the nematode/copepod ratio in organic pollution studies. Mar Environ Res 23:135-152

Raffaeli DG, Mason CF (1981) Pollution monitoring with meiofauna, using the ratio of nematodes to copepods. Mar Pollut Bull 12:158-163

Rodríguez Castelo E, Mora J (1984) Introducción al estudio de una dinámica de poblaciones bentónicas en fangos infralitorales orgánicamente enriquecidos. (Ría de Pontevedra. NW de España). Cuad Area Cienc Mar 1:291-302

Saier B (2002) Subtidal and intertidal mussel beds (Mytilus edulis L.) in the Wadden Sea: diversity differences of associated epifauna. Helgol Mar Res 56:44-50

Sánchez-Mata A, Mora J, Garmendia JM, Lastra M (1993) Estructura trófica del macrozoobentos submareal de la ría de Ares-Betanzos. I: Composición y distribución. Publ Espec Inst Esp Oceanogr $11: 33-40$

Simboura N, Zenetos A (2002) Benthic indicators to use in Ecological Quality classification of Mediterranean soft bottom marine ecosystems, including a new biotic index. Medit Mar Sci 3(2):77-111

Surugiu V (2005) The use of polychaetes as indicators of euthrofication and organic enrichment of coastal waters: A study caseRomanian Black coast. Anelele Stiintifice ale Universitatii "Al. I. Cuza" Iasi, s. Biologie animala 51:55-62

Svane I, Setyobudiandi I (1996) Diversity of associated fauna in beds of the blue mussel Mytilus edulis L.: effects of location, patches size, and position within a patch. Ophelia 45:39-53

Tebble N, Chambers S (1982) Polychaetes from Scottish waters. Part I. Family Polynoidae. Royal Scottish Museum Studies, 73 pp

Timm T (1999) A guide to the Estonian Annelida. Estonian Academy Publishers, Tartu-Tallinn

Tsutsumi H (1990) Population persistence of Capitella sp. (Polychaeta; Capitellidae) on a mud flat subject to environmental disturbance by organic enrichment. Mar Ecol Prog Ser 63:147-156

Ude H (1929) Oligochaeta. In: Dahl F (ed) Die Tierwelt Deutschlands und der angrenzenden Meeresteile nach ihren Merkmalen und nach ihrer Lebensweise, 15. Gustav Fischer, Jena, pp 1-132

Villalba A, Viéitez JM (1985) Estudio de la fauna de anélidos poliquetos del sustrato rocoso intermareal de una zona contaminada de la Ría de Pontevedra (Galicia). 1. Resultados biocenóticos. Cah Biol Mar 26:359-377

Villalba A, Viéitez JM (1988) Polychaetous annelids from the intertidal rocky substratum of a polluted area of the ria de Pontevedra (Galicia, Spain). 2. Taxonomic aspects with the description of Lugia atlantica, n. sp. Proc biol Soc Wash 101:176-182

Warwick RM (1981) The nematode/copepod ratio and its use in pollution ecology. Mar Pollut Bull 12:329-333

Wiederholm T (1980) Use of benthos in lake monitoring. J Water Pollut Cont Fed 52:537-547

Wiens JA, Parker KR (1995) Analyzing the effects of accidental environmental impacts: approaches and assumptions. Ecol Appl 5:1069-1083 